\begin{tabular}{|c|c|}
\hline DE GRUYTER & ECONOMIC THEMES (2017) 55(3): 353-376 \\
\hline
\end{tabular}

\title{
CONVERGENCE IN THE FUNCTIONING OF BANKING AND NONBANKING FINANCIAL INSTITUTIONS IN SERBIA
}

\author{
Valentina Nestorov
}

University of Niš, Faculty of Economics, Republic of Serbia

$\triangle$ nikolicvalentina@ymail.com

UDC

336.71(497.

11)

Review

paper
Received:

07.04.2017.

Accepted:

20.08.2017.

\begin{abstract}
In recent decades, the main characteristics of developed countries have been numerous changes in the banking industry, which led to the emergence of new trends. We are faced with the continuing trend of creating new banking products, as a result of the demands and desires of consumers, as well as stronger competition between banks and non-banking financial institutions. Due to increased competition, banks are losing a significant share of the financial market. Due to the new situation, banks are increasingly, in the context of their banking products, including newer services, in order to counter the competition of non-banking financial institution, i.e. banks are beginning to offer non-banking operations. In this way, banks engage in high-risk zone, which, if not directed in the right way can jeopardize banks' operations. The aim of this writing is to highlight the importance of convergence of banking and non-banking financial institutions, which is still underdeveloped in the Serbian market. The purpose is to raise awareness with banks and other non-banking financial institutions that joint cooperation in reference to connectivity can bring benefits financially and in terms of increasing mutual trust of clients and suppliers of services. It could be beneficial to both banks and non-banking financial institutions as well as to final users customers.
\end{abstract}

Keywords: development tendencies of banking, operations of nonbanking institutions, synergy effects, the level of convergence.

JEL classification: C10, D12, G21, G22, G23

\section{Introduction}

The achievements of modern information technologies and their practical application have significantly changed the world of banking. The boundaries between banking and other financial institutions are practically disappearing. Deregulation and liberalization of financial operations, as well as the development of financial markets, allow non-banking financial institutions to deal with jobs that 
were reserved for banks and, as a result, banks enter into the new areas and activities in order to remain present in the market.

The processes of deregulation, competition, globalisation, information progress and diversification of business risk, have led to the rapid development of nonbanking transactions of banks, primarily in Western countries, where these processes are most developed, but also in countries in transition. By applying nonbanking activities the banks could achieve adequate profitability and gain competitive advantage.

The general hypothesis is that the convergence of the functioning of the banking and non-banking financial institutions is a developing tendency, which is a series of financial, technical and organisational actions aimed at creating a new type of financial institution. In order to demonstrate the main hypothesis, it is necessary to show that banks and non-banking financial institutions can offer new services in addition to their primary function, to attract new customers in a unified and complete service. Also, by integrating different types of banking and nonbanking activities financial institutions achieve better utilisation of organisational and human resources, which contributes to the reduction of fixed costs of financial services and has a positive impact on business performance.

The results of the work should show that the insurance companies and pension funds, as institutional investors, are the leading players in the modern global financial markets; that competition in the financial markets causes the expansion of the range of services offered by various organisations: banks, insurance companies, pension funds, which offer a wide range of services not directly related to its core business. Also, the results of the work should help banks in Serbia and other countries in transition to have better insight into future programmes of introducing modern financial products in banks, as well as into ways of their realisation.

\section{The convergence of banking and non-banking financial institutions}

Apart from the process of deregulation, competition, globalisation, information progress, the global economic crisis has also had an impact on the functioning of the banking and non-banking financial institutions. In fact, there was a convergence of institutions, which caused changes in the structure of the financial sector. The participation of banks in the structure of the financial sector began to decline, while the share of non-bank institutions, especially insurance companies in the overall structure of institutional investors varies from country to country. For this reason, convergence has become an interesting topic for many studies.

In economics, the term convergence is used in several approaches. The first is related to the problem of the best financial system that exists in the global capital 
markets (Holz, 2003) in the context of economic history. The second is related to the evolutionary paradigm, according to which the convergence is based on the principle of survival of the fittest. Under such conditions, there is no need for institutional changes, such as the long term encouragement aimed at companies to reduce their costs of outside (borrowed) capital (Bratton, McCaheri, 2000). This perspective describes the institutional competition as the market competition of traditional products. The financial system is here considered as a system of minimal complexity, where the structural connection between components plays no role. It is assumed that the competition and convergence will be modelled according to the result of the most efficient financial system: either the market or an oriented bank (Hansmann, Kraakman, 2000).

Schott, Francis H. (1996) believes that an increasing number of financial institutions perform the convergence of their tasks. This allows financial institutions to develop a complete portfolio of financial services for their clients. Although it is considered that a continuation of this trend is a sure bet, there are a number of limitations, related to the legal and regulatory obstacles to unification, the problems associated with large sizes, a strong likelihood of success for the participants, as well as difficulties in achieving corporate culture between functions ranging from conservatism to mechanical execution of client orders in financial entrepreneurship of high risk.

Bradford and Wonhyuk (2011) disagree about perfect convergence and therefore its expectance. Instead, we should be happy with the functional convergence. They believe that banks regulatory will be an incentive to capital markets and other non-banking financial intermediaries. However, past experience suggests that the transfer of financial flows from the strictly regulated banks to less regulated capital markets and other non-banking financial intermediaries will bring new sources of risk and instability.

Van den Berghe and Verweire K. (1999) described in detail the development of bank-insurance. The leading conclusion is that banks and insurance companies had been working together at the distribution level for a long time, but only from the mid-1980s there was a real convergence of financial services between banking and non-banking institutions. They argue that the greatest convergence is taking place in the financial services industry. They believe that financial institutions should review their core business, and that they will survive and be successful only if they can meet the needs of their customers. They found a corresponding strategic response, which is all finance, or in other terms, bank- insurance.

"In short term, banks will continue to compete in cost reduction and efforts to be more efficient. But in the long run, there are important and legitimate reasons for functions that are combined in new packages. The winner of the future will be the one that succeeds to meet the needs of customers, but not those who use the old institutional arrangements “(Crane \& Bodie, 1996, p.111). 
Crane \& Bodie believe that the quest for higher performance and efficiency increases competition between banks, insurance companies, securities companies, mutual fund companies and other financial companies. These authors believe that this fragmentation of the traditional institutions is a part of the transition to more efficient arrangements. This whole development is not the end point. Some companies continue to be successful, whereas other companies combine functions to meet the needs of the customers and to take advantage of new technologies to produce and deliver products at lower cost.

Patterson (1997) showed that new non-banking investors, including independent funds formed of banks, participated in the market together. From 1989 to 1995 , the share owned by bank investors in non-investment loans declined from over ninety per cent to nearly seventy-five per cent, while the share of non-banking institutions, including insurance and financial companies, grew and exceeded twenty-five per cent, and is still growing rapidly. He also thinks that convergence is evident in the investment management of all institutions - commercial and investment banks, insurance companies, funds. Although the insurance and banking came together, especially in Europe, and increasingly in the United States, it is considered that the development of derivatives is one of the most powerful agents in the process of convergence. Firstly, because the derivatives are not historically identified as an institution, all financial players have used them, as clients and as end users. Secondly, and more importantly, derivatives allow the distribution of financial risks that have always been common to all types of financial products, although in different forms and in different institutions. This allowed banks to make copies of the products, such as some types of insurance.

Over the years insurance companies have been the largest institutional investors in the European Union. For example, in 2013 the total volume of investments of insurance companies reached the amount of over 8.527 billion, which represents roughly $59 \%$ of the total gross domestic product of all EU countries together (Brussels, 2015).

\section{Development trends in the banking sector in Serbia}

During last decades banks have considerably changed their essential characteristics, although it can be said that it is an economic area which gives limited access. There are a number of development trends in the banking industry as a result of the application of modern information technology. There has been the emergence of new jobs in banking so that banks could maintain their position in the market. Banks are increasingly beginning to offer non-banking services, i.e. there is a convergence of banking and non-banking financial institutions. New banking products that are most often used within banking are:

1. electronic banking, 
2. mergers

3. acquisitions and

4. bank insurance.

The basic characteristics of $\boldsymbol{e}$-banking services are (Seity J. et al., 2003): individuality, mobility, independence of time and place, and the flexibility and interactive work.

The advantages offered by e-banking are numerous: with less staff it offers a better quality of services; reduces the number of organisational units of the bank; has the possibility of covering a larger territory; there is a larger number of users to whom services can be offered; commissions are reduced; services are available 24 hours a day, 365 days a year; data processing and performance of transactions and checks are almost immediate; the image of an innovative bank is created; there are better and greater interactive options; it promotes self-service banking and strengthens the competitiveness of the bank.

Further development of e-banking services, especially Internet banking, will depend largely on eliminating the risks associated with electronic banking. In the world electronic banking has long been accepted as the most effective way of doing business. On the other hand, no one in our country had a great experience with e-banking, but all the leading banks in Serbia immediately offered this type of service to their customers.

One of the factors that influence the difficult development of e-banking is the insufficient number of computers. The country has taken some measures to make the machines more affordable and thus more accessible to citizens (such as reduced VAT on computers at $10 \%$ ), and the distribution and availability of high-speed internet is growing.

Figure 1. Percentage of households in Serbia that have a computer, from 2006-2015

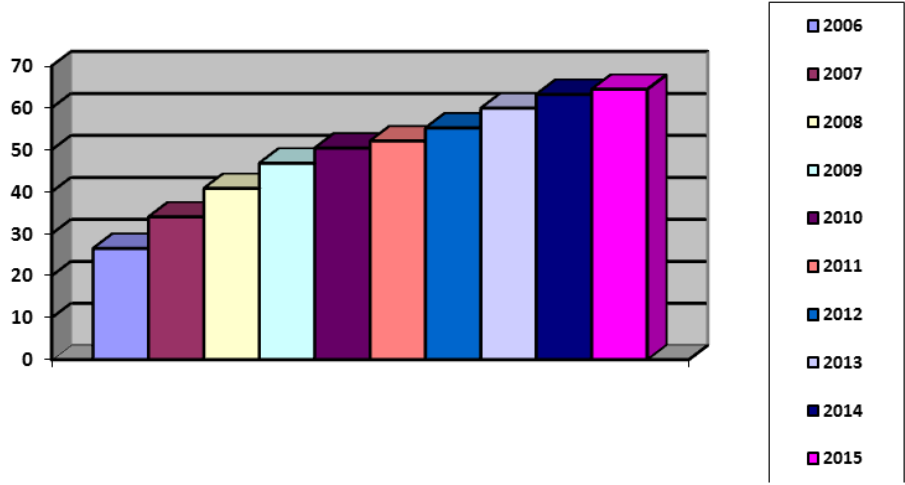

Source: Author, based on data: www.kombeg.org.rs, access date 02.02.2016. 
According to statistics of 2015, 64.4\% of households in Serbia had a computer; in 2014 it was $63.2 \%$, which means that there was an increase of only $1.9 \%$, in 2013 - 59.9\%, which means that there was an increase of $7.51 \%$ and $16.67 \%$ compared to 2012, but compared to 2006 an increase of 143.02\%.

The differences can be seen when comparing the use of computers in Central Serbia and Belgrade.

Modern business banks cannot be imagined without the Internet. Also, research shows that in Serbia in 2009, 36.7\% of households used the Internet, and in 2015 $63.8 \%$, showing an increase of $73.84 \%$, compared to the year 2006 when the use of Internet amounted to $18.5 \%$, recording an increase of $244.86 \%$. Representation of Internet connections in 2015 is higher in Belgrade, which is 71.6\% higher than in the central part of Serbia which is only 57.2\% (Table 1).

Table 1. Households with Internet connection in Serbia in period 2006-2015 in\%

\begin{tabular}{|c|c|c|c|c|}
\hline Region & $\begin{array}{c}\text { Republic of } \\
\text { Serbia }\end{array}$ & $\begin{array}{c}\text { Central } \\
\text { Serbia }\end{array}$ & Belgrade & Vojvodina \\
\cline { 1 - 3 } Year & 18.5 & 15.6 & 22.7 & 19.8 \\
\hline 2006 & 26.3 & 16.5 & 39.1 & 29.2 \\
\hline 2007 & 33.2 & 27.2 & 45.5 & 34.0 \\
\hline 2008 & 36.7 & 30.5 & 48.6 & 37.9 \\
\hline 2009 & 39.0 & 31.7 & 51.3 & 41.8 \\
\hline 2010 & 41.2 & 36.3 & 51.6 & 42.0 \\
\hline 2011 & 47.5 & 40.6 & 60.5 & 49.3 \\
\hline 2012 & 55.8 & 49.0 & 65.8 & 58.3 \\
\hline 2013 & 62.8 & 56.6 & 70.0 & 65.9 \\
\hline 2014 & 63.8 & 57.2 & 71.6 & 67.9 \\
\hline 2015 & & & & \\
\hline
\end{tabular}

Source: http://webrzs.stat.gov.rs/, access date 03.02.2016.

In addition, it is important to point out that in 2015, 30.6\% of Serbia's population has never used the Internet, which is disconcerting.

Banks, telecommunication companies and countries need to work on education, in order to raise the percentage of e-banking. A key prerequisite for the growth of e-banking is the education of the population, and the first step on this path is to eliminate fear among the wider population, so the monetary transactions can take place over the Internet. The growth activity of mergers and acquisitions in the European banking sector began in the 1990s. Since then activity recorded a positive trend with some oscillations.

Greater representation of mergers and acquisitions in Europe began in 1996. In the period since 1999 there has been a rapid growth in bank transactions, resulting in mega-mergers. In this way European megabanks were created, such as: 
BNB Paribas, BBVA, Intesa BCI, Uni Credit, Hypo Vereins Bank. The positive trend of mergers and acquisitions on European and American markets was interrupted in the period from 2001 to 2004. After five years of the falling trend of mergers and acquisitions, in 2015 there was renewed activity growth, which started already in December 2014.

By December 2014 there were 301, whereas in 2013 there were 247. The total value of sales in 2014 was 18.6 billion dollars, compared to the year 2013 when it amounted to 14.5 billion dollars (Figure 2).

Figure 2. Mergers and acquisitions in the European Union in the period 2000-2014

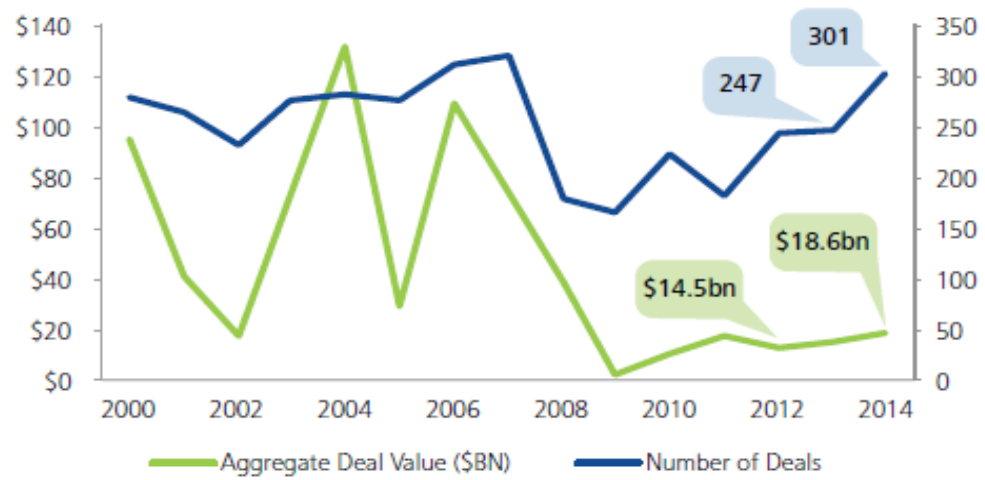

Source: https://www2.deloitte.com/us/en/pages/mergers-and-acquisitions/articles/2015-

banking-m and-a-outlook.html, Deloitte:2015 Banking M\&A Outlook Poised for a rebound, M\&A Institute, p.5., access date 10.11.2016

In Serbia there are also plenty of examples of mergers and acquisitions. The largest number of mergers and acquisitions was recorded in 2005, while their value reached its peak in 2006, when it amounted to the income of 4.387 \$ billion, primarily due to the arrival of Telenor. It should be noted that our country is characterised primarily by acquisition trends. Mergers are much more present in developed countries. Observed by industries, most acquisitions were recorded in financial intermediation and transport sectors (telecommunications). The biggest acquisition in Serbia was made by Telenor by buying Mobtel in 2006 for 1.53 billion Euros. The second largest was conducted in 2003 when the Swiss Philip Morris International Inc. bought from the state $66.45 \%$ stake in the tobacco industry of Nis for 518 million Euros, increasing later investments in Serbia up to the level of 611 million Euros. Also one of the successful examples of foreign investments in Serbia is Fiat's investment in Zastava Kragujevac in 2008 when the company Fiat Automobiles Serbia was founded, where Fiat owns 67\%, and Serbia 
has 33\%. In Serbia, one of the most important mergers was a merger of company NIS by Russian Gazprom Neft. ${ }^{1}$

However, most examples of mergers and acquisitions in domestic practice can be found in the banking sector. Out of 47 banks operating in the Serbian market before the acquisition, 34 operate now. A further decline should be expected in the number of banks. So far, reducing the number of banks was due to acquisitions, but in the future, the motive will be retaining of the market position and an increase of participation. One of the many examples of acquisitions of banks in Serbia is the acquisition of Banca Intesa, which in 2005 merged with Delta Bank, where the value of the transaction amounted to 462 million Euros. Another valuable acquisition in Serbia was carried out in 2006 when the National Bank of Greece (NBG) purchased Vojvođanska Banka ad Novi Sad. The value of the transaction was 385 million Euros. ${ }^{2}$

There are different motives for acquisitions and mergers of banks, such as: profit potential, risk reduction, bailing out banks that fail, the tax motives, favourable market positioning, efficiency and many other motives why the banks opt for mergers and acquisitions with other banking institutions.

The traditional barriers between banking and insurance are increasingly disappearing in the last few decades. This is a result of deregulation and liberalisation of the financial services market, but also the appearance of giant financial companies capable of providing a wide range of financial services, from classic banking, investments, operations with securities and asset management, to insurance services. Providing integrated financial services that characterises financial institutions capable of providing all kinds of financial services under one roof has become a reality. In this regard, there is a large number of new terms, like bank-insurance, " assure finance, assure banque, assure banking, all finance, AllFinanz, integrated financial services ... of which bank assurance stands out.

Bank-insurance products, through connecting banks and insurance companies, allow users of banking products to protect their credit insurance policy and other assets. In this way, banks and insurance companies can effectively solve the problems that may arise for the client.

In Serbia, 20 banks possessed the license to conduct insurance business in 2015. Nevertheless, this market is still not developed enough.

In 2011, the sales network consisted out of 19 banks, which had the required approval, but in 2015 the number of banks that had a license to be insurance agents increased to 20. It is obvious that there is a solid capacity for practicing this method

${ }^{1}$ http://ipf.rs/spajanja-i-pripajanja-aktuelni-primeri-iz-prakse-srbije/, access date10.11.2016.

${ }^{2}$ Similarly, access date 10.11.2016. 
of selling insurance services and they are, for now, far beyond the realised premium. The development of bank insurance depends on many factors: cultural, social, demographic, legal, economic, then the type of business, the extent and modes of organisation and development of banking and insurance.

The motives for the development of bank-insurance are different, both for banks and insurance companies, and consumers. For the banks, the prime interest is to provide customer with complete package of financial services in one place, so they can achieve better capacity utilization and a source of additional income in the form of fees. Insurance companies see bank-insurance as a sales channel for market penetration and increased insurance premiums and lower distribution costs. Unlike banks and insurance companies, the customer benefits from bank-insurance through lower prices, or premiums and he expects high quality products and personal delivery.

In Serbia, Dunav Insurance sells its products over the counter of Komercijalna banka, Čačanska banka and Privredna Banka Beograd. This insurance company, through the bank-insurance, mainly sells simple products compatible with the products of the Bank, as an independent product or with a credit line: life insurance, buildings, auto comprehensive and automobile liability insurance, driver and passenger in the vehicle insurance, roadside assistance, insurance in the case of accident, travel health insurance and others. However, in all European countries, the distribution of insurance products through the branch network of banks has long been accepted as a model.

It can be concluded that the introduction of standard insurance in the portfolio of banking products is certainly a step forward in the development of the so-called bank-insurance in our country. Orientation to this activity provides an opportunity for banks to expand their field of business and the performance of representation. Further, it provides a better positioning in the market, and thus increases the number of customers, because customers, who use different types of insurance, represent for the bank potential users of banking products.

\section{The synergetic effects of the operation of the integrated banking groups in Serbia}

Non-banking operations of banks (insurance operations, operations of pension funds, operations of investment funds, leasing, franchising, forfeiting, factoring, etc.) are modern financial tasks which can be performed independently. However, these tasks are often performed within banks as additional jobs whose purpose is to achieve the greatest possible profit at the bank.

Non-banking operations carry a lower degree of individual risk and long-term sources of financing, and for the banks that carry out these tasks it is an additional 
competitive advantage. The desire for increasing the profitability of banks, as well as the need for greater solvency and liquidity, implies greater use of non-banking operations compared to conventional operations of banks.

In developed countries there is a tendency of development of non-banking financial institutions in the form of non-banking activities within banks. This provides the key aspects of competitive advantage thanks to the synergetic effects of mergers of banks and non-bank financial institutions. Banks thus become sufficiently dynamic and adaptable to and new challenges in the financial markets, and the strengthening of international competition. This leads to the formation of integrated banking groups.

In Serbia, the non-banking operations of the banks are in the phase of implementation and development, and prospects for their further development are great, especially if you take advantage of synergy effects in the development of the entire commercial banking. Due to the new situation another benefit of the banks is to timely adjust their business structure only in case of growing competition and fully utilize the performance of non-banking activities.

Table 2. Share of insurance companies, banks, leasing companies and voluntary pension funds in the financial sector in Serbia in the period from 2013 - 2015 (in\%)

\begin{tabular}{|c|c|c|c|c|}
\hline & & $\begin{array}{c}\text { Balance sheet } \\
\text { total }\end{array}$ & Capital & $\begin{array}{l}\text { Number of } \\
\text { employees }\end{array}$ \\
\hline \multirow{3}{*}{$\begin{array}{l}\text { Insurance } \\
\text { companies }\end{array}$} & 2013 & 4.8 & 5.5 & 29.5 \\
\hline & 2014 & 5.2 & 5.4 & 30.5 \\
\hline & 2015 & 5.8 & 6.7 & 30.5 \\
\hline \multirow{3}{*}{ Banks } & 2013 & 92.4 & 93.5 & 69.0 \\
\hline & 2014 & 92.0 & 93.6 & 67.9 \\
\hline & 2015 & 91.6 & 92.2 & 68.0 \\
\hline \multirow{3}{*}{$\begin{array}{l}\text { Leasing } \\
\text { company }\end{array}$} & 2013 & 2.2 & 0.9 & 1.1 \\
\hline & 2014 & 2.0 & 1.1 & 1.2 \\
\hline & 2015 & 1.8 & 1.2 & 1.2 \\
\hline \multirow{3}{*}{$\begin{array}{l}\text { Voluntary } \\
\text { pension funds }\end{array}$} & 2013 & 0.6 & - & 0.3 \\
\hline & 2014 & 0.7 & - & 0.3 \\
\hline & 2015 & 0.9 & - & 0.3 \\
\hline
\end{tabular}

Source: http://www.nbs.rs/internet/latinica/60/60_6/izvestaji/izv_IV_2015.pdf, access date 16.11.2016

From the table it can be concluded that in Serbia the participation of insurance companies in the financial sector is in the second place, while the first place is taken by the banks. But if you look at the structure of institutional investors, the insurance companies are in the first place. It can be seen that the participation of 
insurance companies in the financial sector increases yearly. In the balance sheet total of the financial sector in 2015, banks accounted for $91.6 \%$, and insurance companies with $5.8 \%$ of the stake. Even though banks control the largest stake, there are synergistic effects and operations between banks and insurance companies.

In Serbia, according to the latest official data, in 2015, 24 insurance companies are operational with over 11.000 employees. Only 20 companies deal with insurance business, and 4 companies deal with re-insurance business. In addition to insurance companies, there are 20 banks in the market that have received approval to conduct activities related to insurance representation. ${ }^{3}$

Based on the above it can be concluded that the number of banks that have a license for insurance representation is approximately the same as the number of insurance companies. The reason for this is that the banks started to deal with the insurance business, but also that there has been a merger and consolidation of companies, in reference to the formation of new integrated banking groups.

Pension funds have similar characteristics as the insurance companies. The inflow of funds has achieved a steady rhythm, and the payments are predictable. This indicates that for them there is no problem of liquidity and that they have made huge financial surpluses which are placed in the capital market (Krstić, 2003, p.106). For pension funds the main characteristic is to hold the controlling stake in the world's largest corporations. The positive effects of the development of pension funds involve strengthening the link between contributions and pensions, creating aggregate demand for securities, capital market development, the creation of longterm sources of funding and increased competition in the financial market. Banks are increasingly beginning to deal with the affairs of pension funds. There are 2 models of creation of pension in household deposits with banks (Jović, 2008, p.121).

One model is saving for retirement (higher credit rating, the possibility of obtaining bank loans, etc., from cross-selling banking market). According to the second model, banks lead their company pension funds or personnel potential balance sheet separately.

The reform of the pension system is inevitable, but before entering the process we must consider in detail the positive and negative effects of each of the possible solutions. The system of compulsory pension insurance in Serbia works on the principle that the currently active working population contributes and finances pension benefits of current retirees. The application of this system of funding calls into question the existence of any Fund, because the contributions paid are

${ }^{3}$ http://www.nbs.rs/internet/latinica/60/60_6/izvestaji/izv_IV_2015.pdf - Sektor osiguranja u Srbiji izvestaj za 2015.godinu, str.12, access date 15.06.2016 
immediately directed to the payment of a pension and all through the interim account'- fund.

Dunav Voluntary Pension Funds were established in 2007 and had a 41.21\% market share. As such it takes the first place, the second place is being held by a voluntary pension fund Delta Generali Basic with a share of 26.85\% (Table 3).

Table 3. Market position of pension funds in the Republic of Serbia, 2016

\begin{tabular}{|l|c|c|c|}
\hline & $\begin{array}{c}\text { Number of } \\
\text { members* }\end{array}$ & $\begin{array}{c}\text { Assets under mil } \\
\text { rsd }\end{array}$ & Share in \% \\
\hline Delta Generali Basic & 43.452 & $8.072,4$ & 26,85 \\
\hline Delta Generali Index & 3.791 & 449,6 & 1,50 \\
\hline Raiffaisen Future & 22.102 & $3.520,7$ & 11,71 \\
\hline Raiffeisen Euro Future & 791 & 15,0 & 0,05 \\
\hline DDOR GarantEkvilibrio & 64.851 & $5.043,7$ & 16,78 \\
\hline DDOR Garant Savings & 14.324 & 572,3 & 1,90 \\
\hline Dunav & 82.915 & $12.388,4$ & 41,21 \\
\hline Total market & 185.560 & $30.062,2$ & 100 \\
\hline
\end{tabular}

* Note: A person may be a member of more funds

Source: Statistical Annex NBS in April 2016, www.nbs.rs

To complete the pension reform in Serbia it is necessary to regulate the work of mandatory and voluntary private pension funds, i.e. the functioning of the second and the third pillar of funding. The speed of the retirement reform will be conditioned by the choice of the right strategy. The development of pension funds in Serbia should be accompanied by a variety of tax incentives to encourage investment in supplementary pension funds.

Investment funds are characterised by high liquidity and very significant financial, which in large quantities buy and sell securities. A large amount of securities trading provides a high level of discounts, up to $90 \%$ of transaction costs, compared to the costs that a single investor would have.

Development of investment funds in Serbia is necessary. In most countries, investment funds are being established mainly by the banks. The main reason for this is that in recent years there has been a spillover of savings from bank deposits into investment funds. For this reason, it is imperative that banks in Serbia, doing it on their own, establish investment funds to hold under control significant transfers of funds into investment funds in order to be able to manage these flows. Also, it 
can be said that the development of investment funds in Serbia has a positive effect on the development of the banks, because the banks could use much stricter criteria of investment funds with the lending bank loans. This would reduce banking risks, and would increase the degree of collectability.

Investment funds have been present in Serbia for ten years, since 2007, when the first funds started working until today. The global financial crisis that erupted in late 2007 and resulted in a large drop in share prices in all world markets has had an impact on the funds in Serbia. In addition to the decline in value of assets that the funds managed, there has been a decline in investor confidence in investments in risky securities. Both of these negative effects have a great influence on the development of the market of investment funds in Serbia, and have resulted in reducing the number of funds and companies which manage them.

In the first two years of operations, our market established 20 investment funds, which were managed by more than ten companies for management. After years of consolidation, reorganisation, acquisitions and mergers of funds, in 2013 there were 11 operating funds and one non-operational (Table 4).

Table 4. Basic indicators of the sector of open investment funds in Serbia in the period from 2007-2014

\begin{tabular}{|c|c|c|c|}
\hline Year & $\begin{array}{c}\text { Number of } \\
\text { funds }\end{array}$ & $\begin{array}{c}\text { Number of investment } \\
\text { units }\end{array}$ & $\begin{array}{c}\text { Total net asset OIF in } \\
\text { rsd }\end{array}$ \\
\hline 2007 & 6 & 3.644 .829 & 4.012 .075 .402 \\
\hline 2008 & 14 & 2.402 .647 & 1.340 .474 .105 \\
\hline 2009 & 15 & 2.156 .867 & 1.035 .981 .297 \\
\hline 2010 & 15 & 1.744 .493 & 1.078 .883 .380 \\
\hline 2011 & 15 & 1.947 .097 & 1.607 .044 .353 \\
\hline 2012 & 16 & 2.331 .690 & 2.324 .588 .939 \\
\hline 2013 & 11 & 4.416 .264 & 5.277 .371 .251 \\
\hline 2014 & 12 & 6.952 .001 & 9.156 .460 .680 \\
\hline
\end{tabular}

Source: Author's calculations, based on data of the Commission for Securities of the Republic of Serbia report of the Commission for Securities of the Republic of Serbia and trends in the securities market in the Republic in the period: January - December (2008, 2009, 2010, 2011, 2012, 2013, 2014, 2015) in Belgrade

From the table we are able to see the movement of trends in the number of open investment funds in Serbia by year. After growing number of open investment funds in the period from 2007 to 2009, stabilisation was achieved. After stabilisation of the number of investment funds, which lasted from 2009-2012, the number of funds decreased and out of 16 operational funds 11 remained. At the end of 2014, 12 open investment funds are operational in Serbia. 
Also, the table shows that by the end of 2007, 3.6 million of investment units were held by the investors. This number has almost doubled by the end of 2014 . However, due to the effects of the global financial crisis of 2008 and 2009 there was a significant decrease in the number of investment units of open investment funds. It means that the global economic crisis has had an impact on the development of investment funds as well as with insurance companies. The decline was interrupted in 2010 when the funds restored investor confidence and steady growth in the number of investment units in the following years. By the end of 2014 there were 6.952.001 registered investment units of the open-end investment funds.

In addition to these activities, the banks were engaged in other contemporary non-banking activities: leasing, franchising, forfeiting and factoring. It can be said that there is an increase of synergistic ratio of the integrated bank in the performance of the group-oriented non-banking activities.

Leasing allows the equipment or consumer durable goods to be rented through the mediation of leasing companies and banks. In most cases banks are the ones that form their own leasing companies, and thus control the entire process of renting, contributing to the development of the market and better placement of goods on the one hand and financial resources on the other. Leasing operations in Serbia currently represent the most dynamic segment of the non-banking financial perspective with high growth rates. These jobs are dominant in Serbia and developed as part of commercial banks through the subsidiary organisational forms, where banks provide indirect placement of money even to those customers who do not have enough of their own capital to purchase the leasing object and do not meet satisfactory criteria for obtaining bank loans.

In Serbia, on $1^{\text {st }}$ March 2017, according to the National Bank of Serbia, there was a total of 16 leasing companies.

Table 5. List of Leasing Companies in Serbia

\begin{tabular}{|l|}
\hline \multicolumn{1}{|c|}{ Name } \\
\hline CA Leasing Serbia doo \\
\hline ERB Leasing doo \\
\hline HETA Leasing doo \\
\hline INTESA Leasing doo \\
\hline LIPAKS doo \\
\hline NBG Leasing doo \\
\hline NLB Leasing doo \\
\hline PIRAEUS Leasing doo \\
\hline PORSCHE Leasing SCG doo \\
\hline PROCREDIT Leasing doo \\
\hline RAIFFEISEN Leasing doo \\
\hline S-Leasing doo \\
\hline
\end{tabular}




\begin{tabular}{|l|}
\hline SOGELEASE Serbia doo \\
\hline UNICREDIT Leasing Serbia doo \\
\hline VB Leasing ad \\
\hline ZASTAVA ISTRABENZ Leasing doo \\
\hline
\end{tabular}

Source: Author, based on data from the site https://www.nbs.rs/internet/latinica/57/57 fl.html, access date 01.03.2017.

Based on the above and based on the presented table, it can be concluded that the number of leasing companies decreased, compared to 2008, when there were 17 leasing companies in total, while in 2017 there were 16 leasing companies. The reason that has led to a reduction in the number of leasing companies, as well as an interruption of their further increase is that the banks have begun to include leasing activities in their regular activity, i.e. they are increasingly starting to provide nonbanking operations.

Franchising in banking lies in the fact that a large bank sells its name and business methods to smaller and independent banks in exchange for a commission to receive and share of profits, while bank franchise remains independent in terms of ownership. This is a classic non-credit business, where the bank without any engagement and placement of its funds generate revenues through commissions and profit sharing. It can be concluded that it is necessary to further develop the franchising as a business method in the banking sector in Serbia, because without this modern business method the most advanced and most profitable banking products such as debit, credit and commercial cards would not be available.

Factoring and forfeiting are needed in Serbia to enable businesses to accelerate the collection of receivables and capital turnover, to facilitate the placement and export and penetration in new markets even in condition of a lack of capital and a lack of creditworthiness.

Forfeiting mechanism is used as a rule in order to satisfy the need for good investment and fixed assets, while factoring deals with sale or export of consumer goods. These non-banking operations would accelerate the flow of goods and services in Serbian businesses; they would contribute to the increase in production and reduction of production costs; they would improve liquidity and increase the potential for traditional bank loans; they would reduce the possibility of creating losses due to insolvency; they would eliminate the risk of rising interest rates in the future and they would influence the reduction of operating costs related to the organisation of services of debt collection and litigation management.

Through factoring indirect short-term lending is being approved to manufacturing and trading companies. Banks provide short-term credit support to a factor, which is usually the bank's factor company, which takes over domestic or export receivables of a company and advances to it $75-90 \%$ of the value of sales 
and exports. In this way, capital turnover is accelerated and penetration of smaller companies into new markets is supported.

According to the Agency for Business Registers in Serbia on 1st March 2017 there are a total of 11 factoring companies; according to data from the Chamber of Commerce of Serbia on $1^{\text {st }}$ March 2017 there are a total of 13 banks involved in factoring.

Table 6. List of factoring companies and banks engaged in factoring in Serbia in period 2016 - 2017

\begin{tabular}{|l|l|}
\hline \multicolumn{1}{|c|}{ Factoring company name } & \multicolumn{1}{c|}{ Bank name } \\
\hline ABL Factor doo Belgrade & $\begin{array}{l}\text { BANCA INTESA AD -Factoring } \\
\text { sector }\end{array}$ \\
\hline AGRO Factoring doo Novi Sad & EUROBANK AD \\
\hline CENTAR Factor doo Belgrade & $\begin{array}{l}\text { ERSTE BANK AD Novi Sad - } \\
\text { Branch office GTC Beograd }\end{array}$ \\
\hline FINERA Factoring doo Belgrade & KOMERCIJALNA BANK AD \\
\hline FOCUS Factor plus doo Belgrade & OTP BANK SERBIA AD Novi Sad \\
\hline GAMICO Factoring doo Belgrade & $\begin{array}{l}\text { RAIFFEISEN BANK AD - } \\
\text { Department for factoring }\end{array}$ \\
\hline $\begin{array}{l}\text { Factoring Company TELEGROUP } \\
\text { FINANCE doo Belgrade }\end{array}$ & $\begin{array}{l}\text { SOCIETE GENERALE BANK } \\
\text { SERBIA AD -Factoring service }\end{array}$ \\
\hline PROFINANCE doo Belgrade & VTB BANK AD Belgrade \\
\hline $\begin{array}{l}\text { Business Society QUICK } \\
\text { FACTORING doo Belgrade }\end{array}$ & UNICREDIT BANK AD \\
\hline First Factor - Factoring doo Belgrade & SBERBANK Serbia AD \\
\hline REAL Factor doo Belgrade & AIK banka AD Serbia \\
\hline & CRÉDIT AGRICOLE Serbia \\
\hline & HALK BANKA AD Belgrade \\
\hline
\end{tabular}

Source: http://pretraga2.apr.gov.rs/FactoringList, access date 01.03.2017., http://www.kombeg.org.rs/Komora/udruzenja/UdruzenjeFinansijskihOrganizacija.aspx?vez $\mathrm{a}=3126$, access date 01.03.2017.

In Serbia in June 2016 there was a total of 10 banks that were engaged in factoring, but in October 2016 the number has increased and now in Serbia, there are a total of 13 banks involved in factoring.

Same as with leasing companies, the author can say that in Serbia there are few factoring companies, and that the number of banks involved in factoring increased, as banks started to include factoring operations in their business activities, with the aim of achieving higher profits.

It can be concluded that the need for the development of factoring and forfeiting operations in Serbia within the framework of non-banking transactions of banks is large, because the banks would thus be able to achieve higher profits. The 
height of this profit is justified and is correlated with the amount of risk and the scope and level of services provided to clients. The attractiveness of these activities is reflected in their relatively simple implementation, flexibility and decisionmaking.

\section{The methodology, assumptions and results of convergence of banking and non-banking activities}

To prove the hypothesis, which is set at the outset, it is necessary to look upon banking and non-banking activities and determine the level of convergence. In regards to passive banking operations, the example of two banks, Komercijalna banka Belgrade and Banca Intesa Belgrade, is used.

Table 7. Total liabilities of Komercijalna banka Belgrade and Banca Intesa Belgrade on $31^{\text {st }}$ December 2015.

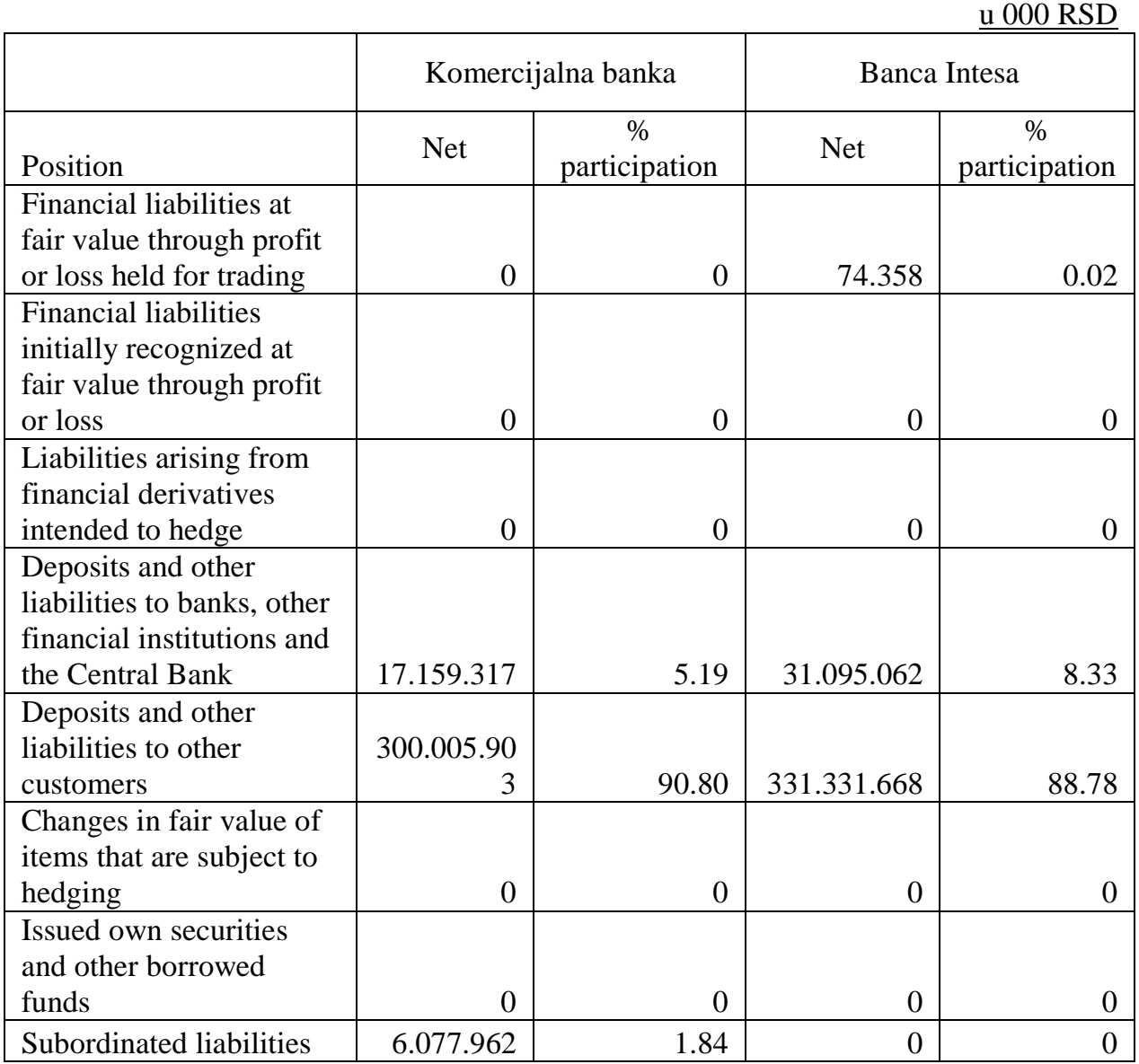




\begin{tabular}{|l|r|r|r|r|}
\hline Provisions & 2.109 .020 & 0.64 & 1.729 .001 & 0.46 \\
\hline $\begin{array}{l}\text { Liabilities from assets } \\
\text { held for sale and assets } \\
\text { of discontinued } \\
\text { operations }\end{array}$ & & & & \\
\hline Current tax liabilities & 0 & 0 & 0 & 0 \\
\hline Deferred tax liabilities & 127.545 & 0 & 679.444 & 0.18 \\
\hline Other liabilities & 4.920 .368 & 1.49 & 8.291 .692 & 2.22 \\
\hline & 330.400 .11 & 100 & 373.201 .225 & 100 \\
\hline
\end{tabular}

Source: Author based on data from: https://www.nbs.rs/internet/latinica/50/50_5.html, access date 10.12.2016.

Based on the table, it can be concluded that most of the liabilities of Komercijalna banka consist of deposits and other liabilities to other clients, with a percentage share of $90.80 \%$. Also, at Banca Intesa Belgrade, most of the liabilities are deposits and other liabilities to other customers, which amount to $88.78 \%$. Behind them are deposits and other liabilities to banks, other financial institutions and the Central Bank with its share of 5.19\% in total liabilities at Komercijalna banka, while Banca Intesa percentage is $8.33 \%$.

Regarding active banking operations the structure is as follows:

Table 8. Total assets of the Komercijalna banka Belgrade and Banca Intesa Belgrade on $31^{\text {st }}$ December 2015

\begin{tabular}{|c|c|c|c|c|}
\hline \multirow[b]{3}{*}{ Position } & \multirow{2}{*}{\multicolumn{2}{|c|}{ Komercijalna banka }} & \multirow{2}{*}{\multicolumn{2}{|c|}{ Banca Intesa }} \\
\hline & & & & \\
\hline & Net & $\begin{array}{c}\% \\
\text { participation }\end{array}$ & Net & $\begin{array}{c}\% \\
\text { participation }\end{array}$ \\
\hline $\begin{array}{l}\text { Cash and balances } \\
\text { with central banks }\end{array}$ & 63.523 .715 & 16.21 & 98.939 .321 & 20.28 \\
\hline Pledged funds & 0 & 0 & 0 & 0 \\
\hline $\begin{array}{l}\text { Financial assets at } \\
\text { fair value through } \\
\text { profit or loss held for } \\
\text { trading }\end{array}$ & 851.056 & 0.22 & 1.431 .783 & 0.29 \\
\hline $\begin{array}{l}\text { Financial assets } \\
\text { initially recognized at } \\
\text { fair value through } \\
\text { profit or loss }\end{array}$ & 0 & 0 & 70.974 & 0.01 \\
\hline $\begin{array}{l}\text { Financial assets } \\
\text { available for sale }\end{array}$ & 127.173 .383 & 32.45 & 78.048 .825 & 16.00 \\
\hline $\begin{array}{l}\text { Financial assets held } \\
\text { to maturity }\end{array}$ & 0 & 0 & 0 & 0 \\
\hline Loans and advances & 16.844 .000 & 4.30 & 36.168 .380 & 7.41 \\
\hline
\end{tabular}




\begin{tabular}{|c|c|c|c|c|}
\hline $\begin{array}{l}\text { to banks and other } \\
\text { financial institutions }\end{array}$ & & & & \\
\hline $\begin{array}{l}\text { Loans and advances } \\
\text { to customers }\end{array}$ & 162.742 .565 & 41.53 & 257.848.609 & 52.86 \\
\hline $\begin{array}{l}\text { Changes in fair value } \\
\text { of items that are } \\
\text { subject to hedging }\end{array}$ & 0 & 0 & 0 & 0 \\
\hline $\begin{array}{l}\text { Receivables from } \\
\text { financial derivatives } \\
\text { intended to hedge }\end{array}$ & 0 & 0 & 0 & 0 \\
\hline $\begin{array}{l}\text { Investments in } \\
\text { associates and joint } \\
\text { ventures }\end{array}$ & 0 & 0 & 0 & 0 \\
\hline $\begin{array}{l}\text { Investments in } \\
\text { subsidiaries society }\end{array}$ & 5.480 .888 & 1.40 & 962.496 & 0.20 \\
\hline Intangible assets & 216.830 & 0.06 & 818.694 & 0.17 \\
\hline $\begin{array}{l}\text { Property, plant and } \\
\text { equipment }\end{array}$ & 6.139 .572 & 1.57 & 8.718.461 & 1.79 \\
\hline Investment properties & 2.744 .026 & 0.70 & 224.358 & 0.05 \\
\hline Current tax assets & 37.017 & 0.01 & 79.396 & 0.02 \\
\hline Deferred tax assets & 0 & 0 & 220.561 & 0.05 \\
\hline $\begin{array}{l}\text { Fixed assets held for } \\
\text { sale and assets of } \\
\text { discontinued } \\
\text { operations }\end{array}$ & 63.314 & 0.02 & 256.254 & 0.05 \\
\hline Other assets & 6.040 .483 & 1.54 & 4.011 .057 & 0.82 \\
\hline TOTAL ASSETS & 391.856 .849 & 100 & 487.799.169 & 100 \\
\hline
\end{tabular}

Source: Author, based on data from the site

https://www.nbs.rs/internet/latinica/50/50_5.html, access date 10.12.2016.

Based on the table shown, it can be concluded that the biggest percentage of assets owned by Komercijalna banka are loans to customers, that make $41,53 \%$ of the total bonds and at Banca Intesa this percentage is 52,86\%. Right after the loans for customers are financial assets available for sale that make $32.45 \%$ of total asset while at Banca Intesa the second position is dominated by cash and mandatory assets pledged into Central Bank.

In order to determine the level of convergence it is necessary to consider banking and non-banking activities together.

Table 9. The banking and non-banking operations of Banca Intesa in 2017

\begin{tabular}{|c|c|}
\hline Banking operations & Non-banking operations \\
\hline $\begin{array}{l}\text { Payment transactions (domestic and } \\
\text { foreign) }\end{array}$ & $\begin{array}{l}\text { Insurance (casco insurance, insurance } \\
\text { housing, international travel insurance, }\end{array}$ \\
\hline
\end{tabular}




\begin{tabular}{|l|l|}
\hline & $\begin{array}{l}\text { risk life insurance, savings and life } \\
\text { insurance) }\end{array}$ \\
\hline $\begin{array}{l}\text { Savings (dinar and foreign exchange, } \\
\text { annuity, Bambino children's savings) }\end{array}$ & Broker - Dealer Operations \\
\hline $\begin{array}{l}\text { Loans (on line cash loan, cash loan, } \\
\text { mortgage credit, loan refinancing, auto } \\
\text { loan) }\end{array}$ & Custody bank \\
\hline Electronic banking & Investment jobs \\
\hline Foreign Affairs & Factoring \\
\hline $\begin{array}{l}\text { Lending economy (short term, long } \\
\text { term loans, credit lines) }\end{array}$ & \\
\hline Documentary and guarantee business & \\
\hline $\begin{array}{l}\text { Loans for working capital to guarantee } \\
\text { European investment Fund }\end{array}$ & \\
\hline EBRD credit line for energy efficiency & \\
\hline $\begin{array}{l}\text { Credit line for energy efficiency and } \\
\text { renewable energy }\end{array}$ & \\
\hline European Investment Bank credit line & \\
\hline $\begin{array}{l}\text { Credit line of the Italian Government } \\
\text { for SMEs and the PUC }\end{array}$ & \\
\hline $\begin{array}{l}\text { Loans for financing agricultural } \\
\text { production }\end{array}$ & \\
\hline Loans for investments in agriculture & \\
\hline Allowed overdraft & \\
\hline Issuance of safes & \\
\hline
\end{tabular}

Source: Author based on data from the site http://www.kombank.com/, http://www.bancaintesa.rs/pocetna.1.html\#menu3, access date 03.01.2017

By applying simple statistical analysis it can be concluded that banking operations are the most dominant in banks, but that the participation of nonbanking activities is not negligible. Based on the presented table, it can be seen that Banca Intesa provides a range of 16 different jobs, 5 of which are non-banking activities, which means that non-banking operations make up a third of the total supply of banking operations.

It can be concluded that in Serbia there is a high level of convergence, because the system offers non-banking activities within banks and they make up a third of the total supply of banking operations. However, although there is a high degree of convergence and offer of non-banking activities within banks, the results in the income statement of banks show that the income from these jobs is only $1 \%$ of total revenue. To achieve a high performance and generate greater profits, it is necessary for banks to exercise the greatest possible introduction of modern 
financial products into banks, as well as ways of their realization. Nevertheless, it is essential that there is greater confidence of citizens.

\section{Conclusion}

The average bank in the world today has more than 200 financial products and services in various combinations, intended to solve the financial problems of any kind. The reason is that banks are increasingly trying to include non-banking operations. The traditional barriers between banking and insurance, and other financial intermediaries are increasingly being erased in the last few decades. This is a result of deregulation and liberalisation of the financial services market.

In Serbia, the non-banking operations of banks are in the phase of implementation and development, and prospects for their further development are great. It is therefore necessary to further develop non-banking operations in Serbia within the framework of the banks, because the banks would thus be able to deliver higher profits compared to the level of a classical term deposits. Also, with the inclusion of non-banking activities to the banks offers, the existing capacities of certain parts of the banks can be used, thus avoiding duplication of effort or capacity. In this way, relatively lower fixed operating costs per unit of financial services are achieved.

Diversification of financial offers by combining banking and non-banking operations allow banks:

- security and stability in business,

- economics of scale, i.e. relatively lower fixed costs,

- elimination of conflicts of interest of various financial institutions and businesses,

- securing long-term sources of funds,

- better maturity compliance of sources of funds and bank lending

- ability to overcome regulatory restrictions,

- favorable competitive position.

It can be concluded that banking and non-banking operations are two inextricable links of the financial sector. It is therefore logical that the models of integrated banking and insurance services are present in our financial market through the bank-insurance model, which is an example of the unbreakable bond of banking and non-banking activities. The synergy between the banking sector and insurance companies is a natural process that results in the reduction of business risk, reduction of the costs of market research as well as the costs of performance in the market which ultimately results in achieving better profitability in the business. 


\section{References}

Agnus, H. (2002).Bancassurance - knowing and growing with your customers. Pricewaterhouse Coopers, Cover Nore July.

Angelov, C.H., Hilgart, M.A., Hogarth J.M. (2004). U.S. Consumers and elektronicBanking 1995-2003. Federal Reserve Bulletin, Winter

Amihud Y., DeLong, G., Saunders, A., (2002)."The effects of cross-border mergers on bank risk and value", J.Int.moneyFinan.21.

Babić HodovićV.(2003).Bankoosiguranje-konkurencija ili kooperacija bankarstva i osiguranja. Svet osiguranja, br.3.

Boyd, J.H, Graham, S.L., Hewitt, R.S. (1993). Bank holding company mergers with nonbank financial firms: Effects on the risk of failure. Journal of Banking and Finance 17.

Bratton, W.,McCahery, J. (2000).The case against global crossreference, in J. A. McCahery, P. Moerland, T. Raaijmakers,L. Renneboog. (Eds.). Corporate governance regimes convergenceand diversity.Oxford: Oxford University Press.

Brussels (2015).Insurance Europe, The benefits of Insurance.

Colin I. Bradford, Wonhyuk Lim, (2011). Global Ledership in Transition making the G 20 more effective and responsive, Korean Development Institute, Brookings Institution Press

Cummins, J.D. (1991). Static and financial models of insurance pricing and the insurance firm", Journal of Risk ind Insurance 58.

Rane, D.B \& Bodie Z. (1996). The transformation of banking: for follows function, Harvard, Business Review, March-April, 109-117

Ćirović, M. (2004).Fuzije i akvizicije. Prometej Novi Sadž

De Nicolo G., Bartholomew P., Zaman J., ZepherinM. (2004).Bank consolidation, internationalization, and conglomeration: trends and implications for financial risk, Financial Markets, Institutions and Instruments 13.

Estrella A. (2001). Mixing and matching: Prospective financial sector Mergers and market valuation, Journal of Banking and Finance 25.

Goddard, J., P.Molyneux, and O.S.J. Wilson, Banking in the European union in Berger A., P. Molyneux, and O.S.J. Wilson (ed), The Oxford handbook of banking, Oxford university press, pp 807-843.

Hansmann, H.; Kraakman, R. (2000). Toward a single model ofcorporate law?, in J. A. McCahery, P. Moerland, T. Raaijmakers,L. Renneboog (Eds.).Corporate governance regimesconvergence and diversity.Oxford: Oxford University Press.

Holz, W. (2003).Convergence of financial systems: towards an evolutionary perspective, Working Paper No. 31 [online].Vienna University of Economics and Business Administration, accessed on: http://epub.wu.ac.at/334/1/document.pdf, accessed on 30.10.2016.

Hoschka, T.C., (1994).Bancassurance in Europe. London, Machmillan.

OECD (2003).Institutional Investors - Statistical Yearbook 1992-2001, Paris OECD Publications,

Jović, Z., (2008). Menadžmentfinansijskihinstitucija.UniverzitetSingidunum, Beograd, str. 121

Jović, Z., (2008).Parabankarsaki i nebankarski poslovi, Beograd.

Klein, R.A. , (2001). Bancassurance in practice, muich Re. Group. 
Krstić, B. (2003).Bankarstvo IV izdanje, Ekonomskifakultet. Niš

Krstić, B.(2004). Bankarskimenadžment, Ekonomskifakultet, Niš

Lewis M. (1990). Banking as Insurance in: E.P.M. Gardener, ed.., The Future of Financial Systems and Services. New York: St. Martin's.

Mladenović,O. (1982). Forfeting kao jedan od oblika finansiranja izvoza. Jugoslovensko bankarstvo, Udruženje banaka Jugoslavije, Beograd 6.

Patterson, E. Michael, (1997). Convergence of Global Financial services, Fordham, International Law Journal, accessed on: http://ir.lawnet.fordham.edu/ cgi/viewcontent.cgi?article $=2240 \&$ context $=\mathrm{ilj}$, accessed on 10.11.2016.

Rose, S.P, Hudgins C. S.(2005). Bankarski menadžment i finansijske usluge, (Urednik izdanje na srpskom jeziku, Vasković Vojkan) Data Status, Beograd.

Rose, S.P. (2005). Menadžmentkomercijalnihbanaka, spajanjeipreuzimanjebanaka: upravljanjeprocesompreuzimanja, Mate-_Zagreb, str.675-698.

Schott, Francis H, (1996). Consolidation and convergence of financial Institutions, Business Economics, October 31-36, accessed on: http://www.freepatentsonline.com/article/BusinessEconomics/18800733.html , , accessed on 11.11.2016.

ShelaghH. (1996). Modernbankingintheoryandpractice, Chichester, JohnWilez\&SonsLtd.

Seity J et all. (2003). Internet Banking - an Overview, Journal of Internet banking and commerce, Vol 3, No 1

Swiss Re,( 2001)., Bancassurance in Practice, Munchen Ruck, Munchen.

Stevanović, R. (2004).Lizing kao metod finansiranja razvoja, Nova trgovina, br.7-8, Beograd.

Teichman, Thomas,(1977)., Forfating, The Banker, III.

Thomas E., Chong Ng, (1999).Financial Services Convergence: Strategic Perspective for Insurance Companies. EDS Insurance

Van den Berghe L.A.A andd Verweire, K, S.W.M Carchon, (1999). Convergence in the financial services industry, Tokyo, accessed at: http://www.oecd.org/finance/ insurance/1915267.pdf, accessed on 15.11.2016.

Walter, I., (2004). Mergers and Acquisitions in Banking and Finance: What Works, What Fails, and Why, Oxford University Press

Zakon o bankama (Sl. Glasnik RS, br. 107/2005, 91/2010 i 14/2015)

Zakon o osiguranju (Sl. Glasnik RS, br. 55/04, 70/04, 61/05, 85/05, 101/07, 63/09 i 107/09

Zakon o penzijskomiinvalidskomosiguranju (Sl. Glasnik RS, br. 34/2003, 64/2004 одлука USRS, 84/2004 - dr.zakon, 85/2005, 101/2005 - др.закон, 63/2006 одлука УСРС, 5/2009, 107/2009, 101/2010, 93/2012, 62/2013, 108/2013, 75/2014 і $142 / 2014)$

Zakon o investicionimfondovima (Sl. Glasnik RS, br. 46/2006, 51/2009 i 31/2011)

http://www.tvojnovac.nbs.rs/edukacija/latinica/20/kartice/el_bankarstvo.html, accessed on 04.11.2015.

http://ipf.rs/spajanja-i-pripajanja-aktuelni-primeri-iz-prakse-srbije/, accessed on 10.11.2016.

http://www.nbs.rs/internet/latinica/60/60_6/izvestaji/izv_IV_2015.pdf, accessed on 16.11.2016.

http://www.nbs.rs/internet/latinica/60/60_6/izvestaji/izv_IV_2015.pdf, datumpristupa 15.06.2016.

http://www.ifgroup.com, accessed on 07.07.2016. 
https://fci.nl/en/about-factoring/statistics, accessed on 08.07.2016. http://www.ifgroup.com, accessed on 08.07.2016.

\section{KONVERGENCIJA U FUNKCIONISANJU BANKARSKIH I NEBANKARSKIH FINANSIJSKIH INSTITUCIJA U SRBIJI}

Apstrakt: Poslednjih decenija razvijene zemlje karakterišu brojne promene $u$ bankarstvu, odnosno došlo je do pojave novih trendova. Stalno je prisutan trend kreiranja novih bankarskih proizvoda, kao rezultat zahteva i želja potrošača, ali i sve jača konkurencija između banaka i nebankarskih finansijskih institucija. Zbog pojačane konkurencije banke su izgubile značajan udeo na finansijskom tržištu. Usled novonastale situacije, banke sve više u okviru svojih bankarskih proizvoda uključuju novije usluge, kako bi parirale konkurenciji nebankarskih finansijskih institucija, odnosno banke počinju da se bave i nebankarskim poslovima. Na taj način banke se upuštaju u zonu povećanog rizika, koji ukoliko se ne usmeri na pravi način može ugroziti poslovanje banke. Cilj ovog rada je da ukaže na značaj konvergiranja bankarskih i nebankarskih finanasijskih institucija, koje je na tržištu Srbije još uvek nedovoljno razvijeno. Svrha je podignuti svest i kod banaka i kod drugih nebankarskih finansijskih institucija, da zajedničkom saradnjom, tj. povezivanjem mogu profitirati i finansijski i u smislu povećanja uzajamnog poverenja klijenata i dobavljača usluga. Takođe, koristi mogu imati, kako banke i nebankarske finansijske institucije, tako i krajnji korisnici - klijenti.

Ključne reči: razvojne tendencije u bankarstvu, poslovi nebankarskih institucija, sinergetski efekti, nivo konvergencije.

\section{Author's biography}

Valentina Nestorov completed her elementary school education with honors and was awarded Vuk Karadzic diploma. After the high school, in 2000 she enrolled in the School of Economics in Nis, completing her education there in 2004 with honors. In 2004, she was admitted to the Faculty of Economics (Department of Financial Management) where she defended her Master's degree thesis on the topic The role of banks in the financial market, completing her studies with the average grade of 10 (ten). In October 2009, she enrolled in doctoral studies at the Faculty of Economics, the module of Finance and Banking. Since 2009 she has been employed at the elementary school Kralj Petar for an indefinite period as a coordinator of accounting and financial operations. 